\title{
The dose-adherence model: a critical review of the computation of level of adherence to antiretroviral drugs
}

\author{
D Ofosu 2*, P Agyei-Baffour², G Acquah-Haqan ${ }^{1}$, AJ Amankwa', ENL Browne ${ }^{2}$ \\ From Frontiers of Retrovirology 2011 \\ Amsterdam, The Netherlands. 3-5 October 2011
}

\section{Objectives}

To develop a model for determining the level of dose adherence of Antiretroviral Therapy (ART) clients from the first day of ART to the day of interview and to determine the dose adherence levels of the ART clients using the model.

\section{Methods}

A cross-sectional study was conducted using pre-tested standardized questionnaires in exitinterviews in three ART centres and eleven social support groups to determine the dose adherence levels of ART clients in the Eastern Region of Ghana. A dose-adherence model was developed from three types of dose records; the observed doses, the expected doses and the missed doses and the frequency at which clients defaulted since commencement of ART. This model encapsulated the short-term recall of missed doses and the long-term default frequency of ART clients to arrive at the observed / expected adherence level ratio; the expected doses being the theoretical number of doses to be taken from the first day of ART to the time of interview and the observed doses being the difference between the expected doses and the missed doses.

\section{Results}

Standard adherence levels derived from the model based on literature were $25 \%$ [1], 50\% [2], 80\% [3] and $100 \%$ [4]. However, $83.2 \%$ of respondents were $100 \%$ adherent having honoured all their re-fill appointments and never

\footnotetext{
2Department of Community Health, School of Medical Sciences, College of Health Sciences, Kwame Nkrumah University of Science and Technology, Kumasi, Ghana

Full list of author information is available at the end of the article
}

missed doses since commencement of ART. 14\% and $1.7 \%$ of the 725 respondents were $80 \%$ and $50 \%$ adherent respectively whereas the remaining $1.1 \%$ were $25 \%$ adherent. Observed adherence levels were statistically significant at a p-value of 0.0517 . Further analyses on factors affecting dose adherence were conducted on the respondent's knowledge, attitudes and practices, sociodemographic features, social support received, ARV dispensing consistency and sources of ART information and there was no significance over the adherence levels. Contrarily, the mechanisms adopted for adherence significantly $(p$-value $=0.0517)$ affected the adherence levels.

\section{Conclusion}

The dose-adherence model complements other methods for deducing client's level of dose adherence by considering the long-term default frequency as an addition to the short-term recall of missed doses or self-report.

\section{Author details \\ 'Komfo Anokye Teaching Hospital, Kumasi, Ghana. ${ }^{2}$ Department of Community Health, School of Medical Sciences, College of Health Sciences, Kwame Nkrumah University of Science and Technology, Kumasi, Ghana.}

Published: 3 October 2011

References

1. Bachiller P, Arrando FR, Liceago G, Iribarren JA, Olloquiegui E: Drug Compliance in Patients Starting Saguinavir. 12th World AIDS Conference Geneva, Abstract 32392; 1998

2. Weiser S, Wolfe W, Bangsberg D, Thior I, Gilbert P, Makhema J: Barriers to antiretroviral adherence for patients living with HIV infection and AIDS in Botswana. Acquired Immune Deficiency Syndrome 2003, 34(3):281-288.

3. Haubrich RH, Little SI, Currier JS, Forthal DN, Kemper CA, Beall GN, et al: The value of patient-reported adherence to antiretroviral therapy in predicting virologic and immunologic response. California Collaborative Treatment Group. AIDS 1999, 13(9):1099-1107. 
4. Paterson DL, Swindels S, Mohr J: Adherence to Protease Inhibitor Therapy and Outcomes in Patients with HIV infection. Annals of Internal Medicine 2000, 133:21A.

doi:10.1186/1742-4690-8-S2-P57

Cite this article as: Ofosu et al:: The dose-adherence model: a critical review of the computation of level of adherence to antiretroviral drugs. Retrovirology 2011 8(Suppl 2):P57.

Submit your next manuscript to BioMed Central and take full advantage of:

- Convenient online submission

- Thorough peer review

- No space constraints or color figure charges

- Immediate publication on acceptance

- Inclusion in PubMed, CAS, Scopus and Google Scholar

- Research which is freely available for redistribution

Submit your manuscript at www.biomedcentral.com/submit 